\title{
FENOMEN PRZESTĘPCZOŚCI GRANICZNEJ NA ODCINKU GRANICY Z OBWODEM KALININGRADZKIM FEDERACJI ROSYJSKIEJ'
}

\section{Charakterystyka odcinku granicy Rzeczypospolitej Polskiej z Obwodem Kaliningradzkim Federacji Rosyjskiej}

Istnienie granic państwowych jest nieodzownie związane z fenomenem przestępczości granicznej. Do szczególnie zagrożonych odcinków polskiej granicy należą odcinki z Ukrainą oraz Republiką Federalną Niemiec. Obecność aktywnego szlaku nielegalnej migracji na południe od granicy RP (trasa Rosja-Białoruś-Ukraina-Słowacja-Austria oraz w wariancie: Słowacja-Czechy-Niemcy-Austria) powoduje występowanie potencjalnego zagrożenia na odcinku granicy z Czechami i Słowacją. Zagrożenie nielegalną migracją morskiego odcinka granicy państwowej nie uległo nasileniu i pozostawało zagrożeniem potencjalnym. Istotnym czynnikiem warunkującym skalę nielegalnej migracji pozostaje obecność aktywnego nielegalnej migracji szlaku wiodącego z Rosji do UE, położonego na południe od granicy RP (Ukraina-Słowacja-Czechy-UE). Według danych Straży Granicznej z 2004 r. istnieją trzy kanały przerzutu nielegalnych migrantów przez terytorium RP:

- Rosja-Ukraina-RP-Niemcy (największa liczba zatrzymań),

- Białoruś-RP-Niemcy (niewielka liczba zatrzymań),

- trasy lotnicze (wiodące przez lotniska międzynarodowe). ${ }^{2}$

Celem niniejszego opracowania jest analiza zjawiska przestępczości granicznej na odcinku granicy z Federacją Rosyjską (Obwodem Kaliningradzkim) dokonana w oparciu o dynamikę i strukturę tego zjawiska.

Praca naukowa finansowana ze środków budżetowych na naukę w latach 2010-2011 jako projekt badawczy. R. Gawryś, Wykrywanie i zwalczanie międzynarodowej przestępczości zorganizowanej, związanej z nielegalna migracja, (w:) M. Wierzbicki, M. Kobylas, B. Pluciński (red.), Rozpoznaj zagrożenia i skutecznie zwalczaj. Międzynarodowa konferencja. Wschodnia granica Unii Europejskiej - transgraniczna przestępczość zorganizowana, Szczytno 2005, s. 129. 
Problem granicy wschodniej był negocjowany przez rząd sowiecki z Wielką Brytanią i USA bez udziału Polski. W czasie konferencji teherańskiej w październiku 1943 r. wielkie mocarstwa osiagnęły zasadnicze porozumienie w sprawie przebiegu przyszłej granicy wschodniej, zgodnie z postulatami sowieckimi, tj. wzdłuż tzw. linii Curzona. ${ }^{3} 16$ sierpnia 1945 r. zawarto Traktat graniczny ze ZSRR. Przebieg granicy określony w 1945 r. został następnie zmieniony umową z 15 lutego o zmianie odcinków terytoriów państwowych. Natomiast odcinek granicy polsko-radzieckiej w części przylegającej do Morza Bałtyckiego został szczegółowo określony w umowie z 5 marca 1957 r.

Zgodnie z zasadami sukcesji państw do umów wyznaczających granice po rozpadzie ZSRR, granice określone w traktacie z 1945 r. zostały przejęte przez sukcesorów: Białoruś i Ukrainę. Potwierdzono je następnie w traktatach o przyjaźni zawartych przez Polskę 18 maja 1992 r. z Ukrainą ${ }^{4}$ oraz 23 czerwca 1992 r. z Białorusia.. ${ }^{5}$

Granica polsko-rosyjska na obszarze dawnych Prus Wschodnich została wyznaczona przez umowę graniczną z 1945 r., a następnie potwierdzona w umowie z 5 marca 1957 r. o wytyczeniu istniejącej granicy państwowej ${ }^{6}$, a po rozpadzie ZSRR przebieg granicy na odcinku z Obwodem Kaliningradzkim Federacji Rosyjskiej potwierdzono traktatem między Rzeczpospolitą Polską a Federacją Rosyjską o przyjaznej i dobrosąsiedzkiej współpracy, podpisanym w Moskwie w dniu 22 maja $1992 \mathrm{r}^{7}$

Granica z Federacją Rosyjską rozciaga się na długości 232,04 km (w tym długość odcinka rozgraniczającego morze terytorialne Rzeczypospolitej Polskiej i Federacji Rosyjskiej - 22,21 km). Stanowi to jedynie 6,8\% długością granicy Polski (morskiej i lądowej).

Zgodnie z rozporządzeniem Ministra Spraw Wewnętrznych i Administracji z dnia 11 grudnia 2001 r. w sprawie utworzenia oddziałów Straży Granicznej ${ }^{8}$ lądowy odcinek granicy polsko-rosyjskiej ochrania Warmińsko-Mazurski Oddział Straży Granicznej w Kętrzynie. Obejmuje on swoim zasięgiem województwo warmińsko-mazurskie z wyłączeniem: powiatu elbląskiego, miasta na prawach powiatu Elbląg, z powiatu braniewskiego gminy Frombork, a także morskich wód wewnętrznych Zalewu Wiślanego. Oddziałowi powierzono odpowiedzialność za ochronę lą-

3 Szerzej: H. Dominiczak, Granice państwa i ich ochrona na przestrzeni dziejów 966-1996, Warszawa 1997, s. $324 \mathrm{in}$.

4 Traktat między Rzeczapospolitą Polską a Ukrainą o dobrym sąsiedztwie, przyjaznych stosunkach i współpracy, sporządzony w Warszawie dnia 18 maja 1992 r. Dz.U. z 1993 r. Nr 125, poz. 573.

5 Traktat między Rzeczapospolitą Polską a Republiką Białoruś o dobrym sąsiedztwie i przyjaznej współpracy, podpisany w Warszawie dnia 23 czerwca 1992 r. Dz.U. z 1993 r. Nr 118, poz. 527.

6 W. Czapliński, A. Wyrozumska, op. cit., s. 186-187.

7 Traktat z dnia 22 maja 1992 r. między Rzeczpospolitą Polską a Federacją Rosyjską o przyjaznej i dobrosąsiedzkiej współpracy, podpisanym w Moskwie Dz.U. z 1993 r. Nr 6, poz. 116.

8 Rozporządzenie Ministra Spraw Wewnętrznych i Administracji z dnia 11 grudnia 2001 r. w sprawie utworzenia oddziałów Straży Granicznej, Dz.U. 2001 r. Nr 152, poz. 1733 z późn. zm. 
dowego odcinka granicy państwowej z Obwodem Kaliningradzkim Federacji Rosyjskiej o długości 198 km 697 m.

Na granicy lądowej z Rosją znajduje się 8 przejść granicznych, w tym 4 przejścia drogowe, 3 kolejowe oraz 1 lotnicze. Lotnicze przejście graniczne obsługuje wyłącznie ruch osobowy, 2 przejścia kolejowe obsługują wyłącznie ruch towarowy, natomiast pozostałe przejścia (4 drogowe i 1 kolejowe) obsługują zarówno ruch osobowy, jak i towarowy.

Od 1 maja 2004 r. odcinek granicy Polski z Rosją można scharakteryzować jako zewnętrzna granicę Unii Europejskiej. ${ }^{9}$

Od momentu przystapienia Polski do Unii Europejskiej odcinki granicy z państwami należącymi do Unii Europejskiej wykazywane są w statystykach Straży Granicznej jako odcinki granicy wewnętrznej, a pozostałe odcinki granicy jako odcinki granicy zewnętrznej Unii Europejskiej. W rzeczywistości odcinki te, aż do 21 grudnia 2007 r. tj. pełnego przystapienia Polski do Układu z Schengen, nie posiadały cech granic wewnętrznych oraz zewnętrznych strefy Schengen określonych w art. 1 Konwencji wykonawczej do Układu z Schengen. ${ }^{10}$

Zgodnie z Decyzją Rady z dnia 6 grudnia 2007 r. w sprawie pełnego stosowania przepisów dorobku Schengen w Republice Czeskiej, Republice Estonii, Republice Łotewskiej, Republice Litewskiej, Republice Węgierskiej, Republice Malty, Rzeczypospolitej Polskiej, Republice Słowenii i Republice Słowackiej ${ }^{11}$ Państwa Członkowskie zaczęły w pełni stosować dorobek prawny Schengen. Decyzją Rady w dniu 21 grudnia 2007 r. została zniesiona kontrola na wewnętrznych granicach lądowych i morskich, a w dniu 30 marca 2008 r. wraz ze zmianą rozkładu lotów na letni została również zniesiona kontrola na granicach powietrznych. ${ }^{12}$

Podstawową konsekwencją przyjęcia dorobku prawnego Schengen ${ }^{13}$ dla ruchu granicznego na granicy wewnętrznej jest możliwość przekraczania granicy w każ-

9 A. Moraczewska, Transformacja funkcji granic Polski, Lublin 2008, s. 135-136.

10 Por. W. Kubacki, Kontrola graniczna na zewnętrznych i wewnętrznych granicach Unii Europejskiej, (w:) A. Tkacz (red.), Integracja RP z Unią Europejską. Zadania Straży Granicznej, Kętrzyn 2000, s. 56.

11 Decyzją Rady z dnia 6 grudnia 2007 r. w sprawie pełnego stosowania przepisów dorobku Schengen w Republice Czeskiej, Republice Estonii, Republice Łotewskiej, Republice Litewskiej, Republice Węgierskiej, Republice Malty, Rzeczypospolitej Polskiej, Republice Słowenii i Republice Słowackiej, Dz. Urz. UE L07.323.34.

12 M. Droździkowska, Schengen z perspektywy polskich doświadczeń, (w:) Polska w strefie Schengen. Refleksje po pierwszym roku doświadczeń, Warszawa 2008, s. 9.

13 Zgodnie z Decyzją Rady z dnia 20 maja 1999 r. dotycząca definicji dorobku Schengen do celów określenia, zgodnie ze stosownymi postanowieniami Traktatu ustanawiającego Wspólnotę Europejską i Traktatu o Unii Europejskiej, podstawy prawnej dla każdego z postanowień lub decyzji stanowiących dorobek Schengen (1999/435/ WE) dorobek Schengen stanowią: 1) Układ podpisany w Schengen dnia 14 czerwca 1985 r. między rządami państw Unii Gospodarczej Beneluksu, Republiki Federalnej Niemiec a Republiką Francuską w sprawie stopniowego znoszenia kontroli wspólnych granic, 2) Konwencja wykonawcza do Układu z Schengen, podpisanego dnia 14 czerwca 1985 r., dotyczącego stopniowego znoszenia kontroli wspólnych granic, podpisana w Schengen dnia 19 czerwca 1990 r. między Królestwem Belgii, Republiką Federalną Niemiec, Republiką Francuską, Wielkim Księstwem Luksemburga a Królestwem Niderlandów oraz Akt Końcowy i towarzyszące deklaracje wspólne, 3) Protokoły i układy o przystapieniu do Układu z 1985 r. i do Konwencji wykonawczej z 1990 r., zawarte z Wło- 
dym jej miejscu bez dokonywania odprawy granicznej osób niezależnie od ich obywatelstwa (art. 20 kodeksu granicznego Schengen ${ }^{14}$ ). Jednakże zniesienie kontroli granicznej na granicach wewnętrznych nie wpływa na wykonywanie uprawnień policyjnych przez właściwe organy Państw Członkowskich na mocy prawa krajowego, o ile wykonywanie tych uprawnień nie ma skutku równoważnego z odprawą graniczną (art. 21 Kodeksu Granicznego Schengen). Zatem od dnia 21 grudnia 2007 r. granica Polski z Rosją stała się zewnętrzną granicą strefy Schengen. ${ }^{15}$

\section{Dynamika i struktura przestępczości na granicy polsko-rosyjskiej}

Funkcjonowanie granic państwowych i ich przekraczanie poza swym pozytywnym wymiarem w postaci przemieszczania ludności oraz towarów ma również wymiar negatywny.

Tabela 1. Liczba podejrzanych przez Straż Graniczną o przestępstwa popełnione w związku z przekraczaniem granicy polsko-rosyjskiej w latach 2001-2010

\begin{tabular}{||c|c|c|c|c|c||}
\hline \hline Rok & $\begin{array}{c}\text { Odcinek granicy } \\
\text { z Rosją }\end{array}$ & $\begin{array}{c}\text { Cała granica } \\
\text { Polski }\end{array}$ & $\begin{array}{c}\text { Granica } \\
\text { wschodnia }\end{array}$ & $\begin{array}{c}\text { \% udział postę- } \\
\text { powań wszcz- } \\
\text { tych na granicy } \\
\text { PL-RU w całej } \\
\text { granicy Polski }\end{array}$ & $\begin{array}{c}\text { \% udział postępowań } \\
\text { wszętych na granicy } \\
\text { PL całej granicy } \\
\text { wschodniej Polski }\end{array}$ \\
\hline 2001 & 807 & 6744 & 2432 & 11,97 & 33,18 \\
\hline 2002 & 330 & 5185 & 1678 & 6,36 & 19,67 \\
\hline 2003 & 368 & 6550 & 2443 & 5,62 & 15,06 \\
\hline 2004 & 552 & 7436 & 2575 & 7,42 & 21,44 \\
\hline 2005 & 522 & 6973 & 2670 & 7,49 & 19,55 \\
\hline
\end{tabular}

chami (podpisane w Paryżu dnia 27 listopada 1990 r.), Hiszpanią i Portugalią (podpisane w Bonn dnia 25 czerwca 1991 r.), Grecja (podpisane w Madrycie dnia 6 listopada 1992 r.), Austria (podpisane w Brukseli dnia 28 kwietnia 1995 r.) oraz Dania, Finlandia i Szwecją (podpisane w Luksemburgu dnia 19 grudnia 1996 r.), jak również towarzyszące Akty Końcowe i deklaracje, 4) Decyzje i deklaracje Komitetu Wykonawczego Schengen, 5) Decyzje podjęte przez Grupę Centralną z upoważnienia Komitetu Wykonawczego. Por. M. Zdanowicz, Ruch osobowy i zniesienie kontroli na wewnętrznych granicach państw w Układzie Schengen i Porozumieniu Wykonawczym a prawo polskie, (w:) Wschodnia granica RP granica zewnętrzną UE, Kętrzyn 2001, s. 13.

14 Rozporządzenie (WE) Parlamentu Europejskiego i Rady z dnia 15 marca 2006 r. ustanawiające wspólnotowy kodeks zasad regulujących przepływ osób przez granice (kodeks graniczny Schengen) - Dz. Urz. UE L105 z 13 kwietnia 2006 r.

15 Konwencja wykonawcza do Układu z Schengen z dnia 14 czerwca 1985 r. między Rządami Państw Unii Gospodarczej Beneluksu, Republiki Federalnej Niemiec oraz Republiki Francuskiej w sprawie stopniowego znoszenia kontroli na wspólnych granicach w artykule 1 rozróżnia dwa rodzaje granic: granice wewnętrzna i zewnętrzne. Granice wewnętrzne oznaczają wspólne granice lądowe umawiających się stron, ich porty lotnicze przeznaczone do rejsów krajowych oraz ich porty morskie przeznaczone do regularnych połączeń promowych, wyłącznie z lub do innego portu na terytoriach umawiających się stron, bez zatrzymywania się w jakichkolwiek portach znajdujących się poza powyższymi terytoriami. Natomiast granice zewnętrzne oznaczaja granice lądowe i morskie umawiających się stron, ich porty lotnicze i morskie, jeżeli nie są one granicami wewnętrznymi. 
Magdalena Perkowska

\begin{tabular}{|l|l|l|l|l|l|}
\hline 2006 & 812 & 7864 & 3801 & 10,33 & 21,36 \\
\hline 2007 & 833 & 6901 & 3743 & 12,07 & 22,25 \\
\hline 2008 & 683 & 4739 & 3122 & 14,41 & 21,88 \\
\hline 2009 & 499 & 5527 & 2984 & 9,03 & 16,72 \\
\hline 2010 & 189 & 5200 & 3314 & 3,63 & 5,70 \\
\hline
\end{tabular}

Źródło: Komenda Główna Straży Granicznej i obliczenia własne.

Analiza dynamiki ogólnej liczby podejrzanych o popełnienie przestępstw w związku z przekraczaniem granicy polsko-rosyjskiej wskazuje jednoznacznie na wzrost tej liczby utrzymujący się do roku 2004. Po przystąpieniu Polski do Unii Europejskiej nastapił lekki spadek tej wartości. Nie można jednak stwierdzić tendencji spadkowej, gdy w kolejnych latach liczba podejrzanych zwiększyła się o ponad 35\%. Należy przy tym pamiętać, iż w ramach dostosowywania polskiej polityki wizowej do systemu wspólnotowego, w związku z planowanym przystąpieniem do Unii Europejskiej, na plan pierwszy wysunęła się kwestia wypowiedzenia umów o ruchu bezwizowym w stosunkach z 15 państwami, których obywatele objęci byli obowiązkiem wizowym przy przekraczaniu zewnętrznych granic Unii Europejskiej. Wśród państw tych, na mocy Rozporządzenia Rady (WE) nr 574/1999 z 12 marca 1999 roku $^{16}$, znajdowały się m.in. Białoruś, Rosja i Ukraina. Zgodnie z założeniami procesu dostosowawczego z dniem 1 października 2003 roku Polska wprowadziła obowiązek wizowy dla obywateli wskazanych państw. Obywatele polscy udający się do Rosji i Białorusi zobowiązani zostali również do posiadania wiz wjazdowych. Wiz z kolei nie wymagała Ukraina. Warto przy tym dodać, iż w stosunkach z Białorusią i Rosją wprowadzeniu wiz towarzyszyło ustanowienie - na zasadzie wzajemności - opłat wizowych. W zależności od rodzaju wizy koszty te ustalono na poziomie od 10 - 12 euro do 50 - 53 euro. Wizy dla obywateli Ukrainy były bezpłatne. Przywołane rozwiązania stanowią istotny przykład tego, w jaki sposób harmonizacja polityki wizowej z wymogami UE wpłynęła na kształt regulacji bilateralnych determinujących skalę i charakter ruchów migracyjnych na polskiej granicy wschodniej jeszcze przed przystapieniem do Unii Europejskiej. ${ }^{17}$

16 Rozporządzenie Rady (WE) nr 574/1999 z dnia 12 marca 1999 określające państwa trzecie, których obywatele podlegają obowiązkowi wizowemu przy przekraczaniu granic zewnętrznych Państw Członkowskich, Dz.U. L 72 z 18.03.1999. Rozporządzenie to zostało zastapione przez: Rozporządzenie Rady (WE) nr 539/2001 z dnia 15 marca 2001 r. wymieniające państwa trzecie, których obywatele muszą posiadać wizy podczas przekraczania granic zewnętrznych, oraz te, których obywatele sa zwolnieni z tego wymogu, Dz.U. L 81 z 21.03.2001.

17 1. Szerzej na ten temat: A. Piekutowska, T. Dubowski, Wschodnia granica Polski zewnętrzna granica UE - konsekwencje dla ruchów migracyjnych do Polski, (w:) J. Jańczak, M. Musiał-Karg (red.), Granice wewnętrzne i zewnętrzne Unii Europejskiej, Poznań 2011, s. 215-230. Szerzej nt. Warunków przekraczania granicy państwowej Polski z Rosja, Białorusią i Ukraina jako zewnętrznej granicy Unii Europejskiej: A. Maksimczuk, L. Sidorowicz, Ochrona granic i obsługa ruchu granicznego, Warszawa 2007, s. 143-158. 
Fenomen przestępczości granicznej na odcinku granicy z Obwodem Kaliningradzkim...

Wprowadzenie wymogów wizowych w 2003 r., które wpłynęło na zmniejszenie osobowego ruchu granicznego na analizowanym odcinku granicy, spowodowało zwiększenie liczby podejrzanych.

Przystąpienie RP do układów z Schengen wprowadziło zmiany w zasadach wjazdu na terytorium RP (terytorium UE) dla obywateli państw trzecich, co niewątpliwie miało wpływ na zmniejszenie ruchu osobowego i środków transportu na granicy z Rosją, Ukrainą i Białorusią.

Obywatele państw trzecich, aby wjechać na terytorium państw Schengen, muszą spełniać określone warunki, tj.: posiadać ważny dokument podróży oraz wizę, jeśli taka jest wymagana od obywateli danego państwa, określić cel podróży oraz posiadać odpowiednie środki na okres pobytu i na powrót. Osoba, która zamierza wjechać na obszar Schengen, nie może figurować również w systemie SIS jako osoba niepożądana lub stanowiąca zagrożenie dla porządku publicznego.

Wprowadzenie nowych wymogów wizowych wpłynęło również na spadek liczby podejrzanych na odcinku granicy z Rosją. Zmniejszenie ruchu granicznego ze wschodnimi sąsiadami Polski wpłynęło również na spadek liczby podejrzanych cudzoziemców, co jest naturalną konsekwencją sytuacji, w której mniejszy napływ cudzoziemców do kraju powoduje zmniejszenie rozmiarów ich przestępczości. Tendencja spadkowa utrzymuje się systematycznie do roku 2011.

Odcinek granicy polsko-rosyjskiej stanowi jeden z najkrótszych odcinków granicy lądowej z państwem sąsiadującym; krótszy jest jedynie odcinek granicy z Litwa $(104,28 \mathrm{~km})$. W związku $\mathrm{z}$ tym analizie zostanie poddany procentowy udział liczby podejrzanych na granicy polsko-rosyjskiej w ogólnej liczbie podejrzanych na wszystkich odcinkach granicy Polski. Należy stwierdzić, iż udział ten jest niewielki, wahający się od 3,6\% do 14,5\% w latach 2001-2010. Do roku 2007 dynamika liczby podejrzanych na odcinku granicy z Rosją wykazuje identyczną tendencję jak na całej granicy Polski. Istotne jest, iż od roku 2008 do 2010, gdy w Polsce rośnie liczba podejrzanych o popełnienie przestępstw granicznych, na granicy z Rosją liczba ta systematycznie maleje. W roku 2010 liczba podejrzanych na granicy z Rosją stanowi jedynie 3,6\% ogółu podejrzanych na granicy.

W tym miejscu pojawia się pytanie o strukturę obywatelstwa podejrzanych. Na podstawie dostępnych statystyk Straży Granicznej można jedynie stwierdzić czy byli to obywatele Polski, czy też cudzoziemcy. 
Wykres 1. Polacy i cudzoziemcy podejrzani przez Straż Graniczną o przestępstwa popełnione w związku z przekraczaniem granicy polsko-rosyjskiej w latach 2001-2010

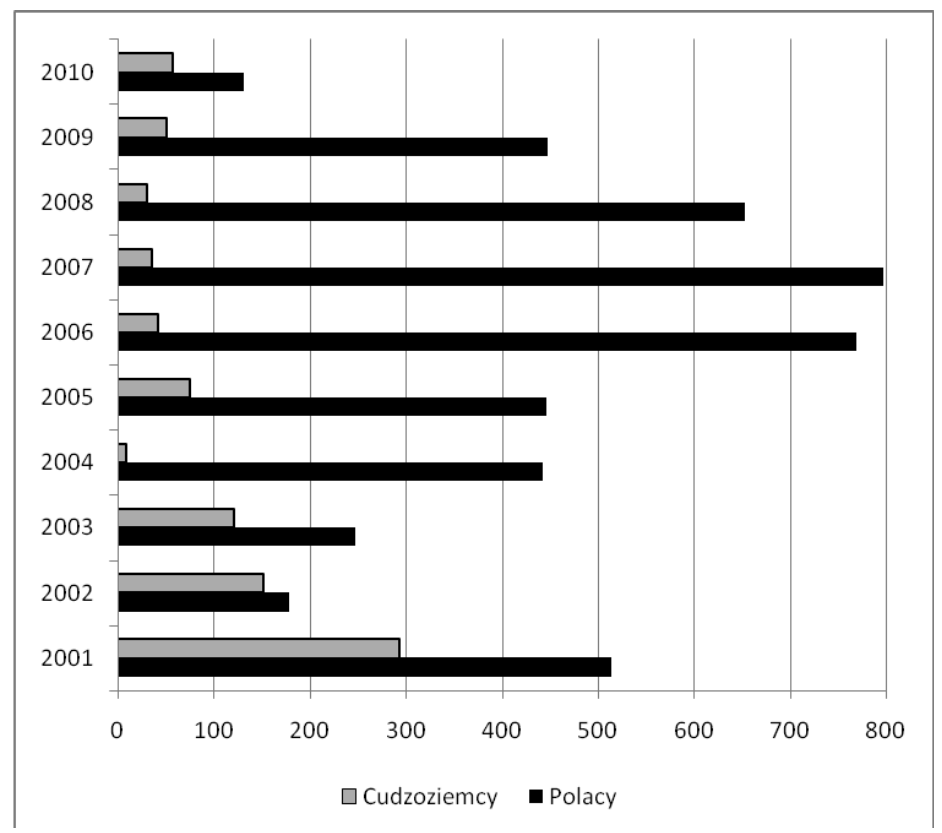

Źródło: Komenda Główna Straży Granicznej.

Analiza danych przedstawionych na wykresie 1. wskazuje jednoznacznie, iż większość podejrzanych o popełnienie przestępstwa w związku z przekraczaniem granicy z Rosją stanowią Polacy. Począwszy od roku 2004, dysproporcja liczby podejrzanych Polaków i cudzoziemców jest większa. Do tego czasu podejrzani cudzoziemcy stanowili 1/3 wszystkich podejrzanych na tym odcinku granicy.

Taką sytuację można wytłumaczyć faktem, iż zmniejszenie ruchu osobowego spowodowane wprowadzeniem wiz uprawniających do wjazdu na terytorium Polski (Unii Europejskiej) dla obywateli państw trzecich przyczyniło się również do spadku liczby przestępstw popełnianych przez cudzoziemców przekraczających granice polsko-rosyjską. Niepokojący jest jednak utrzymujący się od roku 2004 do 2007 wzrost liczby podejrzanych obywateli Polski.

Przedstawiona analiza dynamiki liczby podejrzanych o popełnienie przestępstw w związku z przekroczeniem granicy oraz ich struktura nie jest wystarczająca. Należy przyjrzeć się również strukturze przestępstw popełnianych w związku z przekraczaniem granicy polsko-rosyjskiej. 
Fenomen przestępczości granicznej na odcinku granicy z Obwodem Kaliningradzkim...

Tabela 2. Liczba postępowań karnych wszczętych przez Straż Graniczną na odcinku granicy z Rosją - porównanie do sytuacji na granicy wschodniej do pozostałych odcinków granicy w latach 2001-2010

\begin{tabular}{|c|c|c|c|}
\hline Kwalifikacja prawna & $\begin{array}{c}\text { Cała granica } \\
\text { Polski }\end{array}$ & $\begin{array}{c}\text { Odcinek } \\
\text { granicy z Rosją }\end{array}$ & $\begin{array}{c}\text { \% udział postępowań } \\
\text { wszczętych na granicy PL- } \\
\text { RU w całej granicy Polski }\end{array}$ \\
\hline Art. $264 \S 1 \mathrm{kk}$. & 12978 & 272 & 2,10 \\
\hline Art. $264 \S 2$ kk. & 8598 & 93 & 1,08 \\
\hline Art. $264 \S 3$ kk. & 1254 & 18 & 1,44 \\
\hline Art. $18 \S 3$ kk. w zw. z art. 264 & 1867 & 12 & 0,64 \\
\hline Art. 270 kk. & 11203 & 168 & 1,50 \\
\hline Art. $271-273$ kk. & 1240 & 9 & 0,73 \\
\hline Art. 275 kk. & 349 & 1 & 0,29 \\
\hline Art. $228-228$ kk. & 792 & 172 & 21,72 \\
\hline Art. 258 kk. & 190 & 9 & 4,74 \\
\hline Art. 277 kk. oraz art. 137 kk. & 163 & 1 & 0,61 \\
\hline Art. 85-96 kks. & 12123 & 297 & 2,45 \\
\hline Art. $63-67$ kks. & 19478 & 3259 & 16,73 \\
\hline Art. 54-96 kks. & 389 & 1 & 0,26 \\
\hline Ustawa o przeciwdziałaniu narkomanii & 941 & 12 & 1,28 \\
\hline Ustawa o broni i amunicji & 115 & 8 & 6,96 \\
\hline Ustawa o ochronie dóbr kultury & 552 & 6 & 1,09 \\
\hline Inne przestępstwa & 9484 & 739 & 7,79 \\
\hline RAZEM & 81973 & 5077 & 6,19 \\
\hline
\end{tabular}

Źródło: Komenda Główna Straży Granicznej i obliczenia własne

Struktury przestępstw popełnianych w związku z przekraczaniem granicy polsko-rosyjskiej ujęta w tabeli 2. prezentowana jest w odniesieniu do liczby postępowań karnych wszczętych przez Straż Graniczną dla każdej ze wskazanych kwalifikacji prawnych.

Większość przestępstw (38\%) stanowią tzw. przestępstwa przemytnicze, polegające na sprowadzeniu na terytorium kraju wbrew przepisom ustawy wyrobów akcyzowych bez ich uprzedniego oznaczenia znakami akcyzy. ${ }^{18}$ Przestępstwo zagrożo-

18 Por. G Kędzierska, Przestępczość na granicy polsko-rosyjskiej przed i po wejściu Polski do Strefy Schengen, (w:) M. Zdanowicz (red.), Polska, w Schengen, Białystok 2009, s. 263. 
ne jest karą grzywny do 720 stawek dziennych albo karą pozbawienia wolności do lat 2, albo obu tym karom łącznie (art. $63 \S 2$ kks. ${ }^{19}$ ).

W świetle ustawy o podatku akcyzowym z $2008 \mathrm{r}^{20}$ wyroby akcyzowe stanowią: wyroby energetyczne, energia elektryczna, napoje alkoholowe oraz wyroby tytoniowe. Przestępstwo polega na przemieszczaniu wyrobów alkoholowych i tytoniowych z terytorium państwa członkowskiego na terytorium Polski, nieposiadających znaków akcyzy (określonych przez Ministra Finansów, służących do oznaczania wyrobów podlegających obowiązkowi oznaczania). Mogą one mieć postać banderol, znaków cechowych lub odcisku pieczęci ${ }^{21}$.

Drugą co do wielkości grupę stanowią czyny polegające na nielegalnym przekroczeniu granicy, stanowią one jednak jedynie około $4 \%$ wszystkich wszczętych postępowań. Zbliżone liczby wszczętych postępowań dotyczą przestępstw przeciwko wiarygodności dokumentów oraz przestępstw korupcyjnych.

Niepokojące jest jednak, że ilość postępowań karnych wszczętych o przestępstwa korupcyjne na granicy z Rosją w latach 2001-2010 stanowi aż 21\% wszystkich postępowań wszczętych o te czyny na granicy Polski. Jest to tym bardziej niepokojące, zważywszy na fakt, iż odcinek granicy z Rosja jest jednym z najkrótszych odcinków, a zagrożenie korupcją nieproporcjonalnie duże.

Dane prezentowane przez Straż Graniczną ujmują w jednej kategorii art. 228 i $229 \mathrm{kk}$. Nie pozwala to na stwierdzenie, która strona jest inicjatorem zachowania korupcyjnego. Czy jest to osoba przekraczająca granice, czy osoba pełniąca funkcję publiczną. $Z$ badań prowadzonych przez autorkę wynika, iż większość czynów korupcyjnych polega na przekupstwie lub usiłowaniu przekupstwa funkcjonariuszy Straży Granicznej lub Izby Celnej. Sprawcy, udzielając korzyści majątkowej usiłują nakłonić funkcjonariuszy np. do zaniechania kontroli celnej czy zezwolenia na wjazd na terytorium Polski bez wymaganych dokumentów.

W zestawieniach statystycznych Straży Granicznej czyn zabroniony, polegający na nielegalnym przekroczeniu granicy, ujmowany jest łącznie bez rozróżnienia formy stadialnej, tj. usiłowania i dokonania, jak również bez rozróżnienia od roku 2005, czy jest przestępstwo, czy wykroczenie..$^{22}$ Mimo to prezentowane dane staty-

19 Ustawa Kodeks karny skarbowy z dnia 11 listopada 1999 r., tekst jedn. Dz.U. z 2007 r., Nr 111, poz. 765 z późn. zm.

20 Ustawa z dnia 6 grudnia 2008 r. o podatku akcyzowym, Dz.U. z 2009 r. Nr 3, poz. 11.

21 T. Grzegorczyk, Kodeks karny skarbowy. Komentarz, Warszawa 2009, s. 236. 22 W 2005 roku nastapiła dekryminalizacja zachowania polegającego na przekroczeniu granicy wbrew przepisom. karze ograniczenia wolności albo pozbawienia wolności do lat 2" został uchylony przez ustawę z dn. 22 kwietnia 2005 r. o zmianie ustawy o Straży Granicznej oraz niektórych innych ustaw (Dz.U. Nr 90, poz. 757 z późn. zm.), która weszła w życie 24 sierpnia 2005 r. Natomiast do Kodeksu wykroczeń wprowadzono art. 49a o treści: $\S 1$. Kto wbrew przepisom przekracza granicę Rzeczypospolitej Polskiej, podlega karze grzywny. § 2.Usiłowanie i pomocnictwo sa karalne. 
styczne pozwalają na dokonanie próby określenia skali zagrożenia nielegalną migracją na tym odcinku granicy.

Analiza obywatelstwa sprawców usiłowania lub nielegalnego przekroczenia granicy pozwala na stwierdzenie, iż w latach 2001-2010 obywatele Polski i Rosji stanowili łącznie ponad 75\% zatrzymanych przez Straż Graniczną. Można zatem stwierdzić, iż czynu tego dopuszczają się praktycznie wyłącznie obywatele państw leżących po obu stronach granicy. Przy tym większość stanowią obywatele Rosji, łącznie w analizowanym okresie było to 270 sprawców, tj. 41\%. Polacy stanowili $33 \%$. Jest to naturalne zjawisko, gdyż ludność sąsiadujących ze sobą państw stanowi większość osób przekraczających wspólną granicę, nie zawsze legalnie.

Analizując zatem dynamikę liczby zatrzymanych Polaków w latach 2001-2010, nie jest możliwe stwierdzenie jakiejkolwiek tendencji rosnącej lub malejącej; liczba ta oscyluje między kilkunastu a ponad trzydziestu zatrzymanych.

Podobnie do roku 2007 liczba zatrzymanych obywateli Rosji nie przekraczała rocznie kilku lub kilkunastu osób. Dopiero w roku 2008 nastappił duży wzrost, a jeszcze większy w 2009 roku. Nie była to jednak tendencja stała, gdyż w roku 2010 liczba zatrzymanych spadła do poziomu z lat 2001-2007. Należy przy tym pamiętać, iż dn. 21 grudnia 2007 r. Polska przystapiła do strefy Schengen, a zatem obywateli państw trzecich zaczęły obowiązywać nowe zasady wjazdu na terytorium RP. W związku z tym mogły pojawić się osoby, które usiłowały przekroczyć granicę, nie posiadając wymaganej lub nieodpowiednią wizę. ${ }^{23}$

Kolejną pod względem wielkości grupę stanowili obywatele Armenii, ale było to zaledwie 7\%. Łącznie obywatele państw powstałych po rozpadzie ZSRR stanowili ponad $56 \%$ zatrzymanych.

Poddając analizie dynamikę ogólnej liczby zatrzymanych na granicy polskorosyjskiej należy stwierdzić systematyczny wzrost do roku 2003, po czym liczba zatrzymanych systematycznie malała. Kolejną tendencję wzrostową można stwierdzić w katach 2008-2009, jednak nie jest ona stała, gdyż w 2010 r. odnotowano spadek.

23 Szerzej nt. obowiązków wizowych obywateli państw trzecich: M. Zdanowicz, A. Doliwa-Klepacka, Zmiany zasad w ruchu osobowym,(w:) M. Zdanowicz (red.), Polska w Schengen, Białystok, 2009, s. 11-20; M. Zdanowicz, A. Doliwa-Klepacka, Możliwość liberalizacji reżimu wizowego w ramach współpracy państw w Partnerstwie Wschodnim, (w:) M. Zdanowicz, T. Dubowski, A. Piekutowska (red.), Partnerstwo Wschodnie. Wymiary realnej integracji, Warszawa 2011, s. 151-164. 
Magdalena Perkowska

Tabela 3. Zatrzymani przez Straż Graniczną za nielegalne przekroczenie granicy lub usiłowanie na granicy polsko-rosyjskiej w latach 2001-2010

\begin{tabular}{|c|c|c|c|c|c|c|c|c|c|c|c|}
\hline Obywatelstwo & 2001 & 2002 & 2003 & 2004 & 2005 & 2006 & 2007 & 2008 & 2009 & 2010 & RAZEM \\
\hline Armenia & 3 & 7 & 7 & 17 & & 7 & 0 & 2 & 6 & & 49 \\
\hline Australia & & & 1 & & & & & & & & 1 \\
\hline Białoruś & & & 1 & & & & & 1 & 1 & 1 & 4 \\
\hline Chiny & & & 5 & & & & & & & 1 & 6 \\
\hline Dominikana & & & & & & & & & & 2 & 2 \\
\hline Dżibuti & & & & & & & & & 2 & & 2 \\
\hline Francja & & 3 & 1 & & 1 & & & & & & 5 \\
\hline Gruzja & & & & 1 & & & & & & & 1 \\
\hline Hiszpania & & & & & & & & & 1 & & 1 \\
\hline Indie & & & & & & 2 & & & & & 2 \\
\hline Irak & & & & & & & & & 2 & & 2 \\
\hline Kamerun & & & & & & & & & 1 & & 1 \\
\hline Kazachstan & 1 & & 1 & & & & & & 4 & & 6 \\
\hline Kongo & & & & & & & & & & 1 & 1 \\
\hline Litwa & & & & & & & & 2 & 7 & 3 & 12 \\
\hline Łotwa & & & 1 & & & & & & & & 1 \\
\hline Mołdawia & 1 & & & & & & & & & 11 & 12 \\
\hline Niderlandy & & & & & 1 & & & & & & 1 \\
\hline Niemcy & & & 1 & 2 & & & 5 & 1 & 1 & 3 & 13 \\
\hline Nigeria & & & & & & 1 & & & & & 1 \\
\hline Pakistan & & & 2 & & & & & & 1 & & 3 \\
\hline Peru & & & & & & & 3 & & & & 3 \\
\hline Polska & 18 & 18 & 43 & 34 & 23 & 18 & 13 & 14 & 24 & 12 & 217 \\
\hline Rosja & 6 & 19 & 7 & 8 & 14 & 10 & 19 & 45 & 130 & 12 & 270 \\
\hline Rosja (Czeczenia) & & & & & & & 4 & & & & 4 \\
\hline Somalia & & & & & & & & & 1 & & 1 \\
\hline Syria & & & & & & & & & 3 & & 3 \\
\hline Szwajcaria & & & & & & & & & 1 & & 1 \\
\hline Szwecja & & & & & & & & & 2 & & 2 \\
\hline
\end{tabular}


Fenomen przestępczości granicznej na odcinku granicy z Obwodem Kaliningradzkim...

\begin{tabular}{|c|c|c|c|c|c|c|c|c|c|c|c|}
\hline Tadżykistan & & 1 & 1 & & & & & & & & 2 \\
\hline Togo & & & & & & & & 2 & & & 2 \\
\hline Tunezja & & & & & & & & 2 & & & 2 \\
\hline Turcja & & & & & & & & 2 & & 2 & 4 \\
\hline Ukraina & 2 & & 1 & & & & & 1 & 1 & 3 & 8 \\
\hline Uzbekistan & & & & & & 1 & & & & & 1 \\
\hline Wielka Brytania & & & & & & & & & & 1 & 1 \\
\hline Wietnam & & 1 & 8 & & & & & & & & 9 \\
\hline nie ustalono & & & & & & & & & & 1 & 1 \\
\hline Razem & 31 & 49 & 80 & 62 & 39 & 39 & 44 & 72 & 188 & 53 & 657 \\
\hline
\end{tabular}

Źródto: Komenda Główna Straży Granicznej i obliczenia własne.

Dokonując analizy struktury i dynamiki liczby osób zatrzymanych przez Straż Graniczną za usiłowanie lub przekroczenie granicy wbrew przepisom na odcinku granicy z Rosją, należy jednoznacznie stwierdzić, że jest to zjawisko marginalne w odniesieniu do całej granicy Polski. Liczba zatrzymanych na tym odcinku waha się pomiędzy 1 a $2 \%$ wszystkich zatrzymanych na polskiej granicy. Można zatem stwierdzić, iż nielegalne migracja przez ten odcinek granicy nie stanowi zagrożenia dla żadnego z państw sąsiadujących.

Tabela 4. Liczba zatrzymanych przez Straż Graniczną za nielegalne przekroczenie granicy lub usiłowanie na granicy polsko-rosyjskiej w latach 2001-2010 - porównanie do sytuacji na pozostałych odcinkach granicy w latach 2001-2010

\begin{tabular}{|c|c|c|c|c|c|c|c|c|c|c|}
\hline & 2001 & 2002 & 2003 & 2004 & 2005 & 2006 & 2007 & 2008 & 2009 & 2010 \\
\hline Cała granica Polski & 6184 & 5362 & 5662 & 5762 & 4527 & 4000 & 3222 & 5797 & 3581 & 2349 \\
\hline $\begin{array}{c}\text { Odcinek granicy } \\
\text { z Rosją }\end{array}$ & 31 & 49 & 80 & 62 & 39 & 39 & 44 & 72 & 188 & 53 \\
\hline $\begin{array}{c}\% \text { udział liczby za- } \\
\text { trzymanych na grani- } \\
\text { cy polsko-rosyjskiej } \\
\text { w calej granicy RP }\end{array}$ & 0,50 & 0,91 & 1,41 & 1,08 & 0,86 & 0,98 & 1,37 & 1,24 & 5,25 & 2,26 \\
\hline
\end{tabular}

Źródło: Komenda Główna Straży Granicznej i obliczenia własne. 


\section{Uwagi końcowe}

Analiza zjawiska przestępczości na odcinku granicy z Rosją prowadzi do wniosków, iż jego skala nie jest dominująca w porównaniu z pozostałymi odcinkami granic. Dominującym zjawiskiem jest przemyt, który warunkują różne warunki ekonomiczne w obu państwach, a przede wszystkim różnice w cenach towarów handlowych.

Pomimo niewielkiej skali przestępczości na odcinku granicy polsko-rosyjskiej niepokojący jest rozmiar przestępstw korupcyjnych, w szczególności przekupstwa, które najczęściej towarzyszy przemytowi towarów. Prognoza w tym zakresie nie jest jednak pozytywna. Tak długo, jak będą istniały znaczne różnice w cenach towarów handlowych, a w przypadku Polski i Rosji głównie w cenach papierosów, ich przemyt będzie opłacalny, nawet jeśli w koszt przemytu sprawca będzie musiał wliczyć wartość korzyści majątkowej udzielanej osobie pełniącej funkcję publiczną. 
Fenomen przestępczości granicznej na odcinku granicy z Obwodem Kaliningradzkim...

ФЕНОМЕН ПОГРАНИЧНОЙ ПРЕСТУПНОСТИ НА УЧАСТКЕ ГРАНИЦЫ С КАЛИНИНГРАДСКОЙ ОБЛАСТЬЮ РОССИЙСКОЙ ФЕДЕРАЦИИ

В статье анализируются преступления, совершаемые в связи с пересечением польско-российской границы на пограничном участке с Калининградской областью. Во вступлении рассматриваются правовые аспекты функционирования границы, а также правила ее пересечения гражданами третьих государств. Основная часть работы содержит анализ статистических данных Пограничной охраны, касающихся пограничной преступности в 2001-2010 годы. Исследуется динамика количества лиц, задержанных на этом участке границы, в том числе с точки зрения их гражданства. Интересна также структура преступности, в которой преобладает контрабанда, а нелегальное пересечение границы составляет лишь немногим более 4\% всех возбужденных в этот период уголовных дел. Анализируются также структура и динамика круга и количества лиц, задержанных Погранохраной за попытки или действительное пересечение границы вопреки действующим на рассматриваемом участке правилам. Число задержанных здесь лиц - в пределах 1-2 \% всех задержанных на польской границе. Среди задержанных значительную часть составляют граждане как Польши, так и России. Несмотря на небольшие масштабы преступности на данном участке, вызывает тревогу удельный вес коррупционной преступности, в частности взяточничества, чаще всего сопутствующей контрабандному перемещению товаров. Прогноз в данной сфере не является положительным. До тех пор, пока будут существовать значительные ценовые разницы в отношении товаров, а в случае Польши и России - разница в ценах на сигареты, их контрабанда будет продолжать оставаться окупаемой, даже если в стоимость контрабандного товара будут включены имущественные выгоды, предоставляемые лицу, выполняющему публичные функции. 


\section{THE PHENOMENON OF BORDER CRIME IN THE SECTION OF THE KALININGRAD OBLAST/DISTRICT OF THE RUSSIAN FEDERATION BORDER}

The article explores the phenomenon of crime committed in connection with the crossing of the Polish-Russian border, in the section bordering on the Kaliningrad Oblast/District of the Russian Federation. To begin with, the legal aspects of the functioning of the border and rules concerning crossing it by the nationals of thirdcountries are presented. The most important part of the study includes an analysis of statistical data on border crime in the period 2001-1010, provided by the Border Guard. Data on the dynamics of the number of persons detained in this section of the border - also from the point of view of the nationality of the perpetrators were also analysed. Of particular interest is the type of crime which occurred most commonly, namely smuggling, while illegal crossing of the border occurred in just over 4 per cent of all proceedings initiated in this period.. An analysis of the structure and dynamics of the number of persons detained by the Border Guard for attempts ó to cross or for crossing the border against the law in the section of the Russian border was also carried out. It was confirmed that this is a marginal phenomenon in relation to the entire border of Poland. The number of detainees in this section varies between 1 and 2 per cent of all the detainees on the Polish border. Among those detained, the majority are citizens of Poland and Russia. Despite the small scale of crime along this section of the Polish-Russian border, the extent of offences of bribery and corruption, in particular, which frequently accompanies the smuggling of goods, is alarming. Forecasts in this respect, however, are not positive. As long as there remain significant differences in the prices of goods, in the case of Poland and Russia, mainly in the prices of cigarettes, smuggling will remain profitable, even if the cost of smuggling includes the value of the material benefit provided by the perpetrator to a person exercising functions in the public domain.

Key words:

Border crime, smuggling, bribery, corruption, Kaliningrad Oblast/District 